レター

\title{
グルココルチコイド含有外用剤の長期使用によって 毛包萎縮が広範囲に認められた犬の一例 \\ A Case of Generalized Canine Follicular Atrophy Caused by Long-term Topical Application of Glucocorticoids
}

\author{
塚越 篤 \\ オハナ動物病院 \\ Atsushi Tsukakoshi \\ Ohana Animal Hospital
}

Received August 30, 2014 and accepted October 23, 2014

ステロイドは掻痒や炎症に対し効果的な薬剤で はあるが，長期投与の全身療法では皮膚を含めた 多臓器に生じる副作用が問題になる。外用療法で も全身作用は少ないが, 広範囲に多量に使用する と塗布部位に皮膚萎縮, 紫斑, 面皰, 落屑, ざ瘡 または感染症などの副作用が生じる ${ }^{3)}$ 。ヒトでは ステロイド外用薬を顔面に長期使用することで起 こる酒皶様皮膚炎や，血管支持組織が脆弱化した ステロイド紫斑がよく知られている4)。ステロイ ド外用剂の皮膚症は, 塗布が容易な比較的無毛の 領域でかつ表皮が薄い部位に罹患しやすく，また その結果びらんや局所の潰瘍などが発生し, さら に過剰に局所薬剂を塗布するという悪循環が起こ る ${ }^{1,2)}$ 。そして確定診断に至らないことが多く, 外 用剂の使用期間や経過や予後などについて詳細な 症例の報告がない 1,2$)$ 。

そこで今回，作用強度の弱いトリアムシノロン アセトニド含有の外用ステロイド剤を, 比較的被 毛が多く表皮が薄くない部位に，長期的に継続塗 布したことが原因で，広範囲に皮膚病変を起こし た症例を経験したのでここに報告する。症例は，7 歳歯令, 杂隹種, 去勢オス, 体重 $10.0 \mathrm{~kg}$ 。病歴として, 近医にて約 3 年前に膿皮症と診断され, それから 継続的に抗生剂・抗ヒスタミン郕等の内用薬およ びトリアムシノロンアセトニド含有外用剂を処方

連絡先：塚越 篤（オ八ナ動物病院）

干 248-0013 神奈川県鎌倉市材木座 1-10-3

TEL/FAX 0467-25-3217

E-mail: info@ohana-vet.com
されていた。外用剤の薬剂成分はトリアムシノロ ンアセトニド $0.1 \%$ ・オルビフロキサシン $1 \%$ ・ミ コナゾール硝酸塩 $1 \%$ の合剤であった。ステロイ ド剂の全身投与は一切行われていない。外用剤に ついては, 皮膚の発赤や掻痒を起こした際に飼い 主の判断で高い頻度を制限なく約 3 年間, 1 日 2 回ほど継続的に塗布していた。そして通院治療を 継続するも悪化傾向が続いたため当院への受診と なった。

皮膚の状態はステロイド外用部位に一致して, 病変部が全体的に菲薄で, 頸部腹側面・下腹部・ 側腹部・背部・肛門周囲において広範囲に痂皮の 形成や乾皮および脱毛が起こっていた。腹部や特 に鼠径部や腋下部では表層の血管の拡張と紅斑, または軽度の紫斑が認められた。一般全身状態に は異常は認められなかった（図 1)。

基礎疾患の評価を目的とし, 全血球検査, 血液 生化学検査を行ったが, 特記すべき異常は認めず, 甲状腺ホルモン検査も $1.8 \mu \mathrm{g} / \mathrm{dl}$ （基準值 $0.9 \sim 2.9$ $\mu \mathrm{g} / \mathrm{dl}$ ) と正常值であった。また細菌および真菌の 培養検査は㓌性であった。皮膚生検を実施したと ころ, 腫瘍, 感染性の変化は認めず, 軽度の表皮 の菲薄化と毛包周囲の線維化と顕著な毛包の萎縮 が認められた（図 3)。その結果より，副腎皮質機 能立進症を考慮して ACTH 刺激試験を行ったが, 刺激前は $3.8 \mu \mathrm{g} / \mathrm{dl}$ （基準值 $1.0 \sim 7.7 \mu \mathrm{g} / \mathrm{dl}$ ）で，刺 激後は $11.8 \mu \mathrm{g} / \mathrm{dl}$ （基準值 $1.0 \sim 18.0 \mu \mathrm{g} / \mathrm{dl}$ ）であり 異常は認められなかった。以上の臨床的および病 理学的検査結果により，本症例をグルココルチコ 

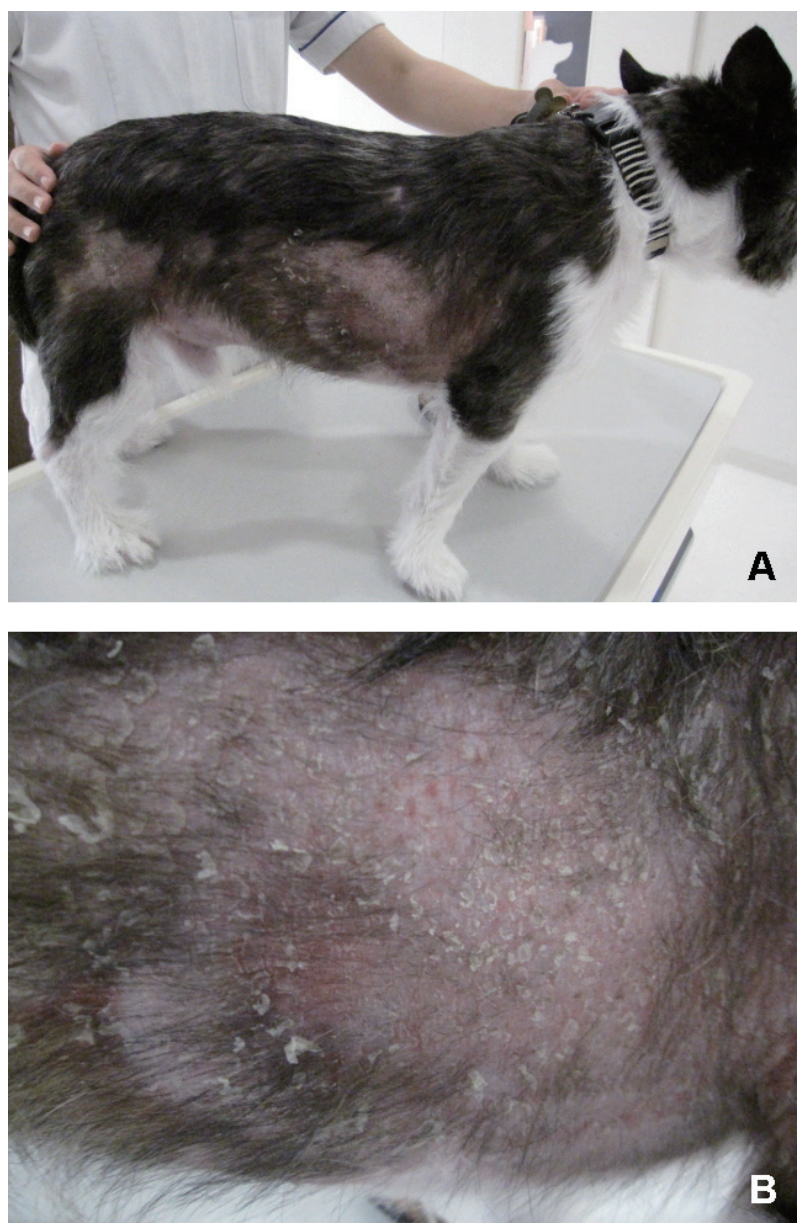

図 1 初診時の皮膚所見

側腹部における脱毛（A）と拡大写真（B）

イド含有外用剂の長期使用の副作用による皮膚症 と診断した。

治療は，ただちにステロイド含有外用剤の中止 を指示し, 菲薄化した表皮や乾皮または紫斑に対 する補助療法として皮膚代謝改善や保湿を目的に ビタミン E（ユベ-E 錠 $100 \mathrm{mg}$, 鶴原製薬，大阪） $50 \mathrm{mg} / \mathrm{head}$ bid, L- システイン（ハイチオール錠 40 $\mathrm{mg}$, 久光製薬, 東京) $40 \mathrm{mg} / \mathrm{head}$ bid の経口投与, ஸ3-6 必須脂肪酸を主成分とする ATOP7 スプレー (ATOP7 SPRAY, Dermoscent, France) の局所投与を 適宜行った。外用剤を中止した後はリバウンドと 思われる, 従来からあった病変部に掻痒を伴わな い軽度な紅斑の悪化を起こした。さらに従来の病 変部以外の皮膚に紅斑を伴わない掻痒が発現した。 ただし軽度であったため一過性のものと考えて経 過観察としたところ，一週間ほどで徐々に病状は 自然消失した。そして，その後の継続治療により 28 病日には発毛が確認され，56 病日には略治した (図 2)。
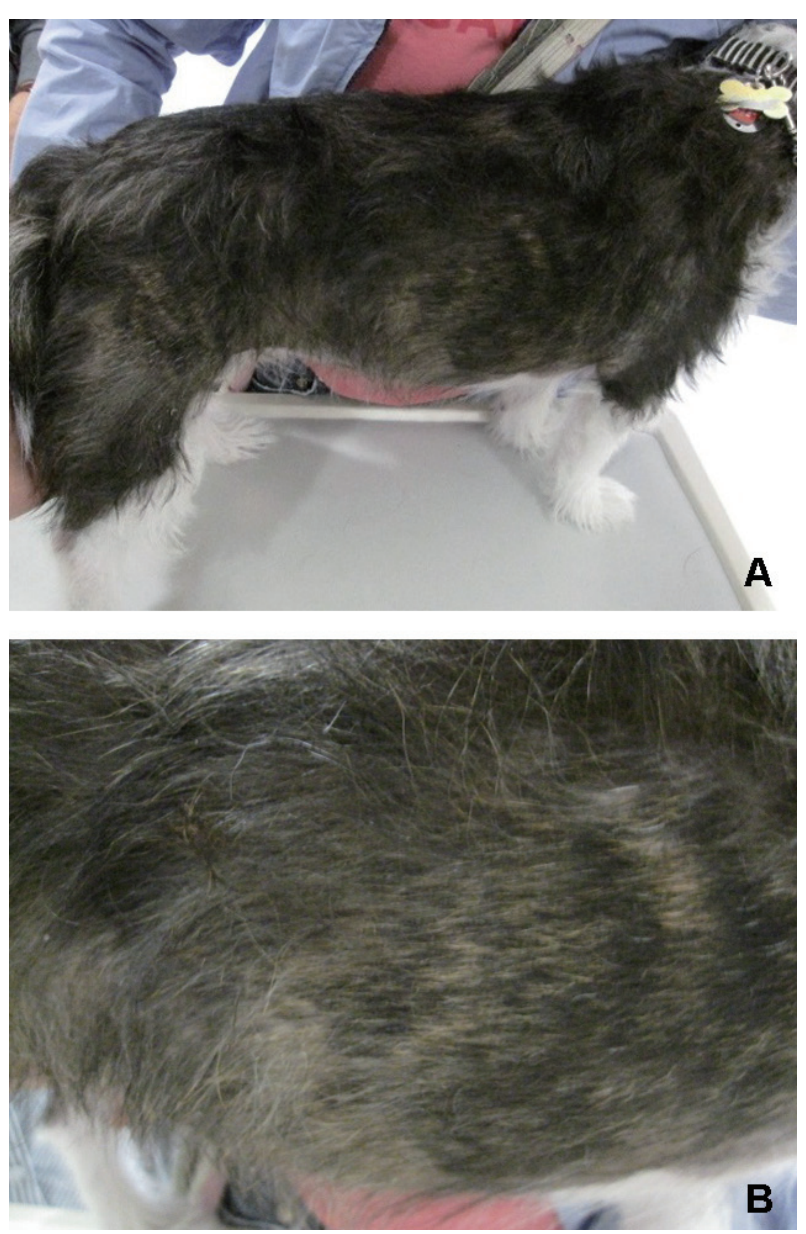

図 2 第 56 病日の皮膚所見

側腹部における発毛（A）と拡大写真（B）

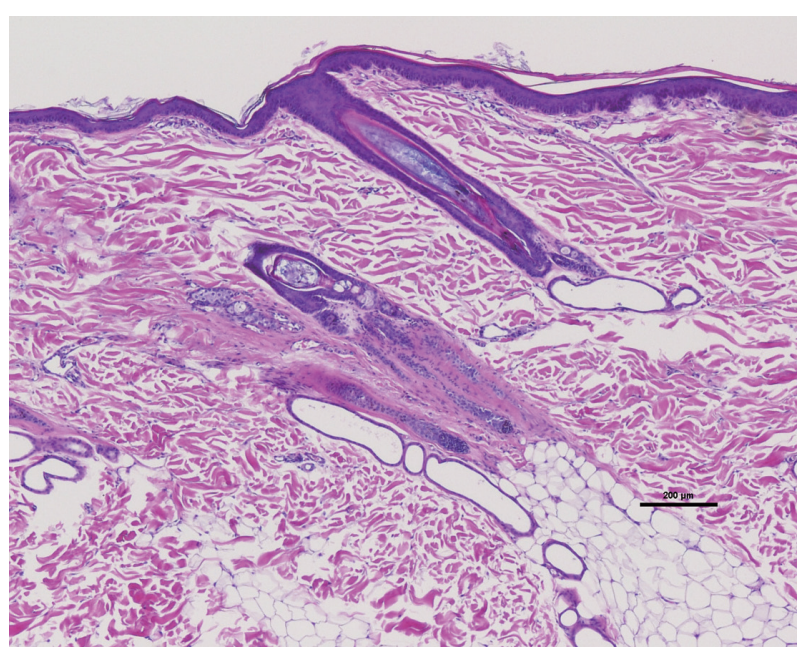

図 3 皮膚病理組織所見 弱拡大像

表皮の菲薄化と毛包周囲の線維化と顕著な毛包の萎縮が認 められた。 
ヒトの場合，ステロイド外用剤による酒輠様皮 膚炎では，ステロイドを中止した上で尋常性痤瘡に 準じた治療を行い,リバウンドが激しい場合はステ ロイド外用薬の使用量を徐々に減らしていく4)。今 回の症例では, 外用ステロイド剤による皮膚症が 主要病変であり, 感染症もなくリバウンドが軽度 であったために，ステロイドの中止とともに皮膚 代謝の改善を図ることで軽快したと思われる。ス テロイド外用剤によって起こる皮膚症は, 長期的 になると外用剤を使用する背景にあった炎症性疾 患との鑑別が難しくなる。また，このような病変 にはステロイド外用剤の適応には慎重に考慮する 必要があり，また使用方法や副作用など飼い主へ の十分な教育およびインフォームドコンセントの 重要性も示唆された。

\section{引用文献}

1) Gross, T.L., Ihrke, PJ., Walder, E.J. and Affolter, V.K. 2009. pp. 521-525. 犬と猫の皮虐病 第 2 版, インターズー, 東京.

2) Miller, W., Griffin, C. and Campbell, K. 2013. Muller \& Kirk's Small Animal Dermatology, 7th ed., Elsevier, St. Louis: 127-129.

3）柴田久美子. 2013。 獣医臨床皮膚科 19: 161165.

4）清水 宏. 2005. pp. 318-319. あたらしい皮 膚科学, 中山書店, 東京. 